Fibroblast migration, proliferation, extracellular matrix protein synthesis and degradation, all of which play important roles in inflammation, are them selves induced by various grow th factors and cytokines. Less is known about the interaction of these substances on lung fibroblast function in pulmonary fibrosis.

The goal of this study was to investigate the effects of PDGF alone and in combination with IL-1 $\beta$ and TNF- $\alpha$ on the production of human lung fibroblast matrix metalloproteinases, proliferation, and the chemotactic response. The assay for MMPs activity against FITC labeled type I and IV collagen was based on the specificity of the enzyme cleavage of collagen. Caseinolytis and gelatinolytic activities of secreted proteinases were analyzed by zymography. Fibronectin in conditioned media was measured using human lung fibronectin enzyme immunoassay. Cell proliferation was measured by $3 \mathrm{H}$-Thymidine incorporation assay. Cell culture supernatants were tested for PGE2 content by ELISA. Chemotactic activity was measured using the modified Boyden chamber.

Matrix metalloproteinase assay indicated that IL$1 \beta$, TNF- $\alpha$ and PDGF induced in testitial collagenase (MMP-1) production. MMP assay also indicated that IL- $1 \beta$ and TNF- $\alpha$ had inhibitory effects on MMP2,9(gelatinaseA,B) production. Casein zymography confirmed that IL-1 $\beta$ stimulated stromlysin (matrix metalloproteinase 3 ; $M M P-3$ ) and gelatin zymography demonstrated that TNF- $\alpha$ induced MMP-9 production in human lung fibroblast, whereas PDGF alone did not. PDGF in combination with IL-1 $\beta$ and TNF- $\alpha$ in duced MMP-3 and MMP-9 activity, as de monstrated by zymography. PDGF stimulated lung fibroblast proliferation in a concentration-dependent manner, whereas $I L-1 \beta$ and TNF- $\alpha$ alone had no effect. In contrast, the proliferation of human lung fibroblasts by PDGF $w$ as inhibited in the presence of IL-1 $\beta$ and TNF- $\alpha$, and this inhibition was not a consequence of any elevation of PGE2. PDGF stimulated fibroblast chemotax is a concentrationdependent manner, and this stimulation was augmented by combining PDGF with IL-1 $\beta$ and TNF- $\alpha$.

These findings suggested that PDGF differentially regulated MMPs production in combination with cytokines, and further that MMP assay and zymography had differential sensitivity for detecting MMPs. The presence of cytokines with PDGF appears to modulate the proliferation and chemotax is of human lung fibroblasts.

Key words: Metalloproteinase, PDGF, IL- $1 \beta$, TNF- $\alpha$, Lung fibroblast, Human

\section{Differential regulation of metalloproteinase production, proliferation and chemotaxis of human lung fibroblasts by PDGF, Interleukin-1 $\beta$ and TNF- $\alpha$}

\author{
Masahiro Sasaki ${ }^{\mathrm{CA}}$, Masayuki Kashima, \\ Takefumi Ito, Akiko Watanabe, Noriko Izumiyama, \\ Masaaki Sano, Manabu Kagaya, Takanobu Shioya \\ and Mamoru Miura
}

Second Department of Internal Medicine, Akita University School of Medicine,1-1-1 Hondo, Akita 010, Japan

${ }^{\mathrm{CA}}$ Corresponding Author
Tel: $+81-18-884-6107$
Fax:+81-18-836-2612
Email: masahiro@im2.med.akita-u.ac.jp

\section{Introduction}

Pulmonary fibrosis and other fibrotic lung diseases are characterized by diffuse intestitial inflammation and exaggerated collagen accumulation. This in turn leads to destruction of alveolar structures and remodeling. ${ }^{1}$
Fibroblast migration, proliferation, extracellular matrix protein synthesis and degradation, all of which play important roles in inflammation, are themselves induced by various cytokines, such as IL- $1 \beta$ and TNF- $\alpha$, and growth factors, such as TGF and PDGF, as well as by the combined use of these agents. $^{2-8}$ Less is known about the interaction of 
these substances on lung fibroblast function in pulmonary fibrosis.

Recent studies have shown that some extracellular matrix components, including collagen, fibronectin and cytokines (e.g. PDGF and TGF) have an effect on fibroblast chemotactic responses. ${ }^{3,8}$ The role of PDGF in combination with cytokines in fibroblast collagen production or degradation is unclear. By using a Boyden chamber to assay chemotaxis, the migration of fibroblasts across collagen-coated filters was shown to be a response to proteinase products of fibroblasts as well as to the products of malignant cells. ${ }^{9,10}$ Stromelysin (matrix metalloproteinase-3, MMP-3) and the type IV procollagenase (matrix metalloproteinase-9, gelatinase $B$ ) are known to degrade a wide range of extracellular matrix molecules, including proteoglycan, gelatin, type IV and $\mathrm{V}$ collagen, and fibronectin.

Recent evidence suggests that matrix metalloproteinases (MMPs), including MMP-2(gelatinase A), MMP-3 and MMP-9 play major roles in the degradation of the extracellular matrix in tumor invasion. ${ }^{10-13}$ Interestingly, cytokines when applied in combination can stimulate the release of these proteinases from fibroblasts, which degrade to a number of structural proteins of the extracellular matrix, in addition to intestitial collagen. ${ }^{14,15}$

The present study investigated the effect of PDGF alone and in combination with IL-1 $\beta$ and TNF- $\alpha$ on MMPs production, proliferation and the chemotactic response of human lung fibroblast in vitro.

\section{Materials and methods}

\section{Materials}

Recombinant human PDGF-BB was purchased from Genzyme (MA, USA). IL-1 $\beta$ was purchased from Otsuka Pharmaceutical Co (Tokushima, Japan) and TNF- $\alpha$ were from Hayashibara Biochemical Laboratories Inc (Okayama, Japan).

\section{Cell culture}

Human lung fibroblasts CCL-153 obtained from the American Type Culture Collection (ATCC) were cultured in a cell culture flask, in modified Ham's F12 (SIGMA) medium supplemented with $10 \%$ fetal calf serum at $37^{\circ} \mathrm{C}$ in an atmosphere of $5 \% \mathrm{CO}_{2}$ and $95 \%$ air and plated at a density of $1.0 \times 10^{5}$ cell in a 24 -well plate until confluence.

\section{Metalloproteinases (MMP) assay}

The assay for MMPs activity against FITC labeled type I and IV collagen was based on the specificity of the enzyme cleavage of collagen. One unit of collagenase activity was defined as the amount of enzyme degrading $1 \mu \mathrm{g}$ of collagen per minute at $37^{\circ} \mathrm{C}$. The specificity of the assay was confirmed by identification of collagenase reaction products by immunofluoresence electrophotometry, as described previously. $^{16}$

\section{Zymographic analysis of metalloproteinases}

Caseinolytis and gelatinolytic activities of secreted proteinases were analyzed by zymography according to the methods of Chin et al. ${ }^{14}$ with some modifications. SDS-polyacrylamid gels contain $1.25 \mathrm{mg} / \mathrm{ml}$ casein or $1 \mathrm{mg} / \mathrm{ml}$ gelatin. Samples to be tested were mixed with an equal volume of the concentrated SDS sample buffer and then electrophoresed on casein or gelatin-containing gels. After electrophoresis of the gels, the separated proteinases were renatured by gentle shaking of the gel in $2.5 \%$ Triton $\mathrm{X}-100$ containing $50 \mathrm{mM}$ Tris- $\mathrm{HCl}$ and $0.1 \mathrm{~m} \mathrm{NaCl}$ at room temperature for $1 \mathrm{~h}$ to remove SDS, followed by incubation in $250 \mathrm{ml}$ of $50 \mathrm{mM}$ Tris- $\mathrm{HCl}$ containing $10 \mathrm{mM} \mathrm{CaCl} 2$ and $0.02 \mathrm{NaN}_{3}$ at $37^{\circ} \mathrm{C}$ for approximately $18 \mathrm{~h}$. The resultant gels were stained with Coomassie brilliant blue.

\section{Fibronectin assay}

Fibroblasts were incubated in serum-free F12 medium or with growth factor and cytokines for $24 \mathrm{~h}$. Fibronectin in conditioned media was measured using human lung fibronectin enzyme immunoassay according to the manufacturer's instructions, purchased from Paesel (Frankfurt, Germany).

\section{${ }^{3} \mathrm{H}$-Thymidine incorporation assay}

Cells were incubated in serum-free F12 medium, or with growth factor and cytokines for $24 \mathrm{~h}$ and then pulsed with ${ }^{3} \mathrm{H}$-Thymidine $(0.04 \mu \mathrm{Ci} / \mathrm{ml})$. Incorporation of ${ }^{3} \mathrm{H}$-Thymidine was measured $24 \mathrm{~h}$ later by detaching cells with trypsin solution and harvesting the cells on filters using a cell harvester. Radioactivity on the filters was determined using scintillation counting.

\section{Prostaglandin $E_{2}$ assay}

Cell culture supernatants were tested for $\mathrm{PGE}_{2}$ content by ELISA kits according to the manufacturer's instructions (purchased from Neogec Corporation).

\section{Chemotaxis assay}

Chemotactic activity was measured using the modified Boyden chamber as described previously. ${ }^{9}$ The chemotactic agent was diluted in Ham's F12 medium and placed in the lower well chamber. The lower well was then covered with a collagen-coated polycarbo- 


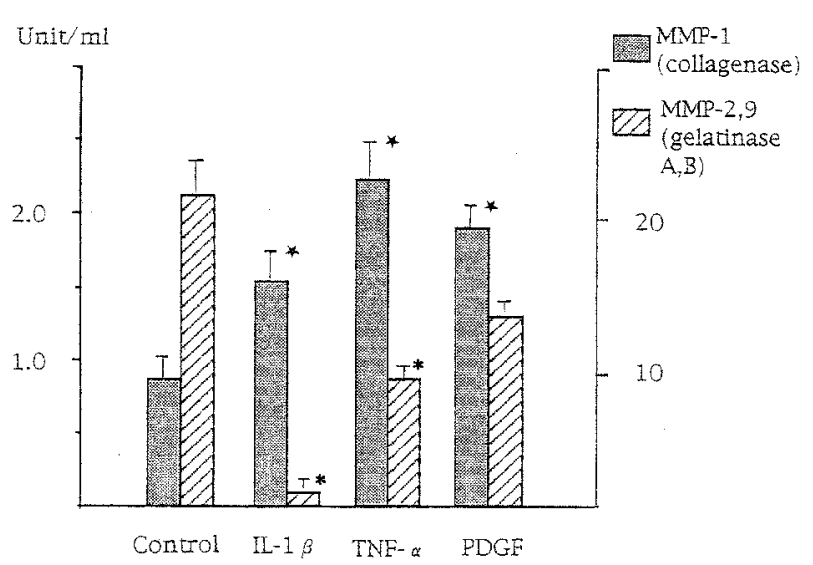

FIG. 1. Matrix metalloproteinases activity in human lung fibroblasts stimulated for $24 \mathrm{~h}$ with $\mathrm{IL}-1 \beta(10 \mathrm{ng} / \mathrm{ml})$, TNF- $\alpha$ $(10 \mathrm{ng} / \mathrm{ml})$ and PDGF $(5 \mathrm{ng} / \mathrm{ml})$. Bar graph representing the activity of MMP-1, light-shaded column and MMP-2,9, oblique-lined column.

nate filter. Human lung fibloblasts $\left(5 \times 10^{4}\right.$ cells $)$ were added to the upper well of the chamber containing Ham's F12 medium. After $8 \mathrm{~h}$ incubation at $37^{\circ} \mathrm{C}$ in $95 \%$ air and $5 \% \mathrm{CO}_{2}$, the filters were removed and cells were fixed and stained using Diff-Quik stain. The chemotactic respose was analyzed by counting the number of cells/microscopic field on the lower surface of the filter. The stimulation index (SI) was expressed as follows: $\mathrm{SI}=$ number of migrating cells with PDGF or cytokines/number of migrating cells without PDGF.

\section{Data analysis}

A comparison of proliferation and chemotaxis within experiments was performed using Student's $t$-test. Statistical significance was accepted at $p<0.05$.

\section{Results}

\section{Matrix metalloproteinase production}

IL-1 $\beta$, TNF- $\alpha$ and PDGF caused a significant increase in matrix metalloproteinase activity (MMP1 ; Fig. 1). In contrast, MMP-2,9 activity was significantly reduced by IL $-1 \beta$, TNF- $\alpha$ and PDGF (Fig. 1). TNF- $\alpha$ alone and PDGF in combination with IL$1 \beta$ and TNF- $\alpha$ stimulated MMP-9 production in lung fibroblasts, whereas neither PDGF alone nor IL-1 $\beta$ alone did so (Fig. 2a). Various combinations of PDGF with IL- $1 \beta$ or TNF- $\alpha$ also induced MMP-3 activity (Fig. 2b).

\section{Fibronectin production}

IL-1 $\beta$ and TNF- $\alpha$, either alone or in combination, both failed to significantly alter basal fibronectin

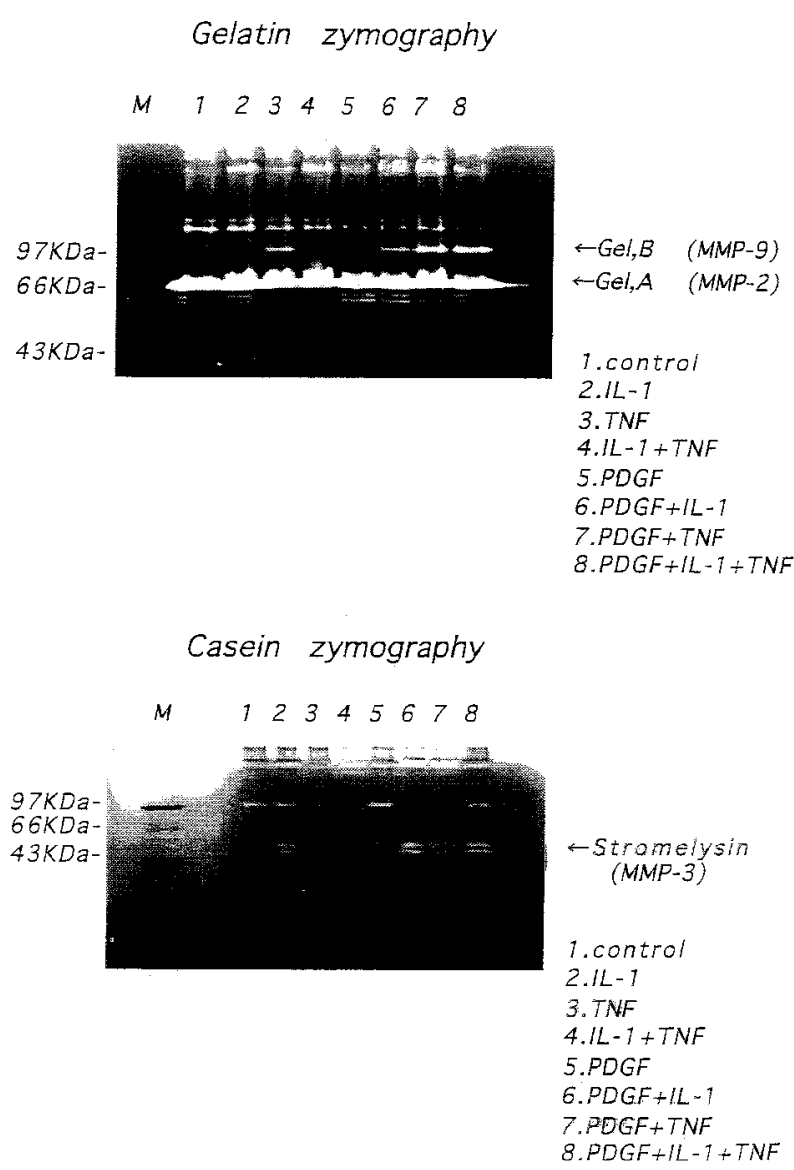

FIG. 2. Zymographic analysis of metalloproteinase expression by fibroblasts treated with PDGF, IL-1 $\beta$ and TNF- $\alpha$. (a) Supernatants from untreated fibroblasts (lane 1) or fibroblasts treated (lanes 2-8) for $24 \mathrm{~h}$ with PDGF $(5 \mathrm{ng} / \mathrm{ml})$, IL$1 \beta(10 \mathrm{ng} / \mathrm{ml})$, or TNF- $\alpha(10 \mathrm{ng} / \mathrm{ml})$ or in combination were analyzed by gelatin zymography for detection of MMP-2 and MMP-9. (b) Supernatants from untreated fibroblasts (lane 1) or fibroblasts treated (lanes 2-8) for $24 \mathrm{~h}$ with PDGF $(5 \mathrm{ng} / \mathrm{ml}), \mathrm{IL}-1 \beta(10 \mathrm{ng} / \mathrm{ml})$, or TNF- $\alpha(10 \mathrm{ng} / \mathrm{ml})$ or in combination were analyzed by casein zymography for detection of MMP-3.

production in human fibroblasts in culture in the absence of PDGF (Fig. 3, $p>0.05$ ). In contrast, PDGF alone $(10 \mathrm{ng} / \mathrm{ml})$ significantly stimulated fibronectin production (control $2.2 \pm 0.4 \mu \mathrm{g} / \mathrm{ml}$ vs PDGF $10 \mathrm{ng} / \mathrm{ml}$ $4.3 \pm 0.7 \mu \mathrm{g} / \mathrm{ml}, p<0.05$; Fig. 3). However, both IL $-1 \beta$ and TNF- $\alpha$, as well as the combination of these cytokines, significantly inhibited the increase in fibronectin production induced by PDGF (10 ng/ $\mathrm{ml})(p<0.05$; Fig. 3).

\section{Fibroblast proliferation}

PDGF stimulated proliferation as assessed by 3H-Thymidine incorporation in fibroblasts (control $2050 \pm 298 \mathrm{dpm}$, PDGF $1 \mathrm{ng} / \mathrm{ml} 3490 \pm 350 \mathrm{dpm}$, PDGF

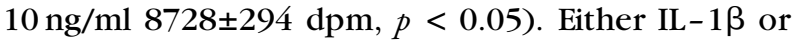
TNF- $\alpha$ alone failed to significantly alter basal proliferation in human fibroblasts cultured with PDGF (data not shown). The proliferation of human lung fibro- 


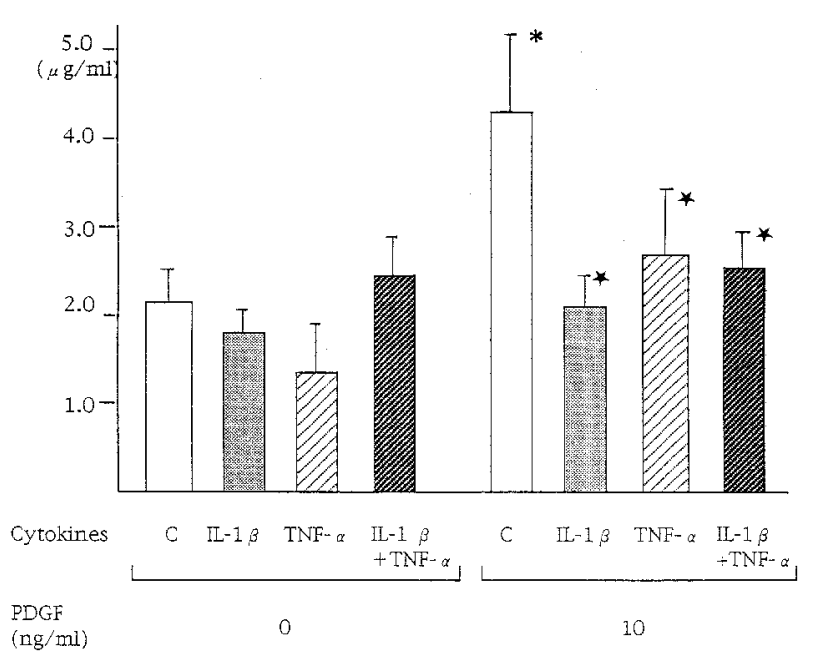

FIG. 3. Fibronectin production in human lung fibroblasts stimulated for $24 \mathrm{~h}$ with PDGF $(5 \mathrm{ng} / \mathrm{ml}), \mathrm{IL}-1 \beta(10 \mathrm{ng} / \mathrm{ml})$, or TNF- $\alpha(10 \mathrm{ng} / \mathrm{ml})$. Bar graph representing tha fibronectin production stimulated by IL- $1 \beta$, light-shaded column, TNF- $\alpha$, oblique-lined column and in combination, dark-shaded column.

blasts by PDGF was significantly inhibited in the presence of IL- $1 \beta$ and TNF- $\alpha$ in combination but this effect only achieved statistical significance with PDGF $(10 \mathrm{ng} / \mathrm{ml} ; p<0.05$, Fig. 4).

\section{Prostaglandin $E_{2}$ assay}

Under basal conditions, human lung fibroblasts in culture produced very little $\mathrm{PGE}_{2}(<0.5 \mathrm{ng} / \mathrm{ml})$. Incubation of human lung fibroblasts with IL-1 $\beta$ (10 ng/ $\mathrm{ml})$ or TNF- $\alpha(10 \mathrm{ng} / \mathrm{ml})$ alone or in combination for $24 \mathrm{~h}$ did not significantly increase $\mathrm{PGE}_{2}$ production (Table 1). Incubation of human lung fibroblasts with IL- $1 \beta(10 \mathrm{ng} / \mathrm{ml})$ or IL-1 $\beta(10 \mathrm{ng} / \mathrm{ml})$ in combination with TNF- $\alpha(10 \mathrm{ng} / \mathrm{ml})$ for $72 \mathrm{~h}$ increased $\mathrm{PGE}_{2}$ production, which inhibited fibroblast proliferation (Table 1). PDGF did not augment the $\mathrm{PGE}_{2}$ production induced by $\mathrm{IL}-1 \beta(10 \mathrm{ng} / \mathrm{ml})$ or TNF- $\alpha$ $(10 \mathrm{ng} / \mathrm{ml})$ alone or in combination for $24 \mathrm{~h}$.

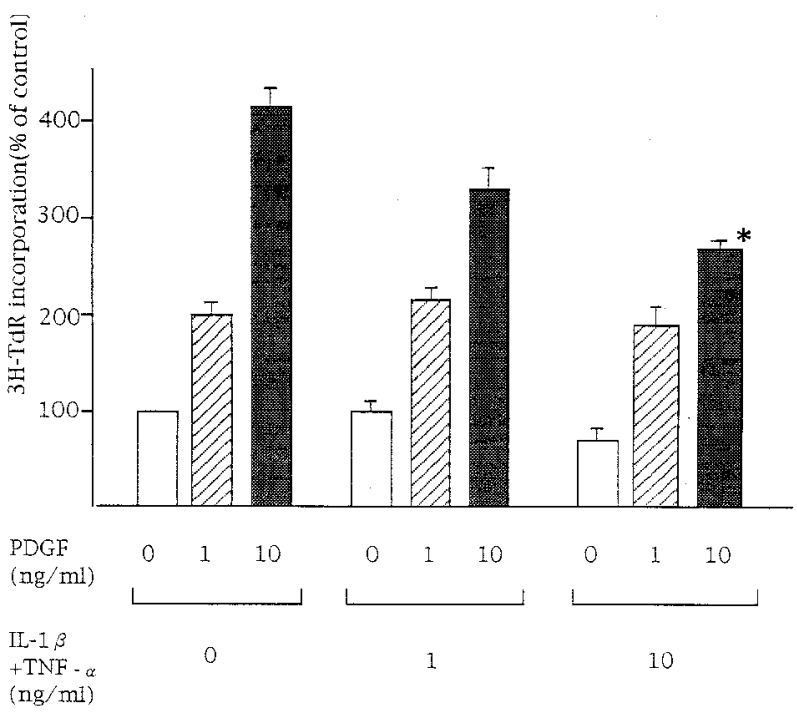

FIG. 4. Effects of PDGF, IL-1 $\beta$ and TNF- $\alpha$ in combination on $3 \mathrm{H}$-Thymidine incorporation by fibroblasts. The average cpm incorporated by untreated fibroblasts was defined as 100 . Values give incorporation of specified radiolabeled substances as percentage incorporation. Bars indicate means with SEM derived from one of three experiments with six replicates for each mean. $p<0.05$ compared with untreated fibroblasts.

\section{Fibroblast chemotaxis}

Neither IL-1 $\beta$, TNF- $\alpha$ nor the combination of these two cytokines significantly stimulated fibroblast chemotaxis in the absence of PDGF (Fig. 5). In contrast, PDGF $(10 \mathrm{ng} / \mathrm{ml})$ significantly increased fibroblast chemotaxis (control $3.8 \pm 0.5$ cells vs PDGF $8.5 \pm 0.5$ cells, $p<0.05, \mathrm{SI}=2.3 \pm 0.2)$, whereas $\mathrm{IL}-1 \beta$ $(p<0.05$ cf. control) and TNF- $\alpha(p<0.05$ cf. control) significantly inhibited chemotaxis induced by PDGF $(10 \mathrm{ng} / \mathrm{ml})$. However, no significant inhibition was observed when both cytokines were present (Fig. 5).

\section{Discussion}

In pulmonary fibrosis, the fibrotic process is thought to be initiated by a variety of events following cell migration including extracellular matrix degradation,

Table 1. The effect of $\mathrm{IL}-1 \beta$ and TNF- $\alpha$ either alone or in combination on fibroblast $\mathrm{PGE}_{2}$ production. $\mathrm{PGE}_{2}$ was measured by ELISA as described in Materials and Methods

\begin{tabular}{lrr}
\hline Cytokines & \multicolumn{2}{c}{ Level of $\mathrm{PGE}_{2}(\mathrm{ng} / \mathrm{ml})$} \\
\cline { 2 - 3 } & $24 \mathrm{~h}$ & $72 \mathrm{~h}$ \\
\hline $\mathrm{IL}-1 \beta(10 \mathrm{ng} / \mathrm{ml})$ & $<0.5$ & $3.65+3.0$ \\
TNF- $\alpha(10 \mathrm{ng} / \mathrm{ml})$ & $<0.5$ & $0.84+0.6$ \\
IL-1 $\beta+$ TNF- $\alpha$ & $<0.5$ & $8.06+4.5$ \\
IL-1 $\beta(10 \mathrm{ng} / \mathrm{ml})+$ PDGF $(5 \mathrm{ng} / \mathrm{ml})$ & $<0.5$ & \\
TNF- $\alpha(10 \mathrm{ng} / \mathrm{ml})+$ PDGF $(5 \mathrm{ng} / \mathrm{ml})$ & $<0.5$ & \\
IL-1 $\beta+$ TNF- $\alpha+$ PDGF & $<0.5$ & \\
& &
\end{tabular}




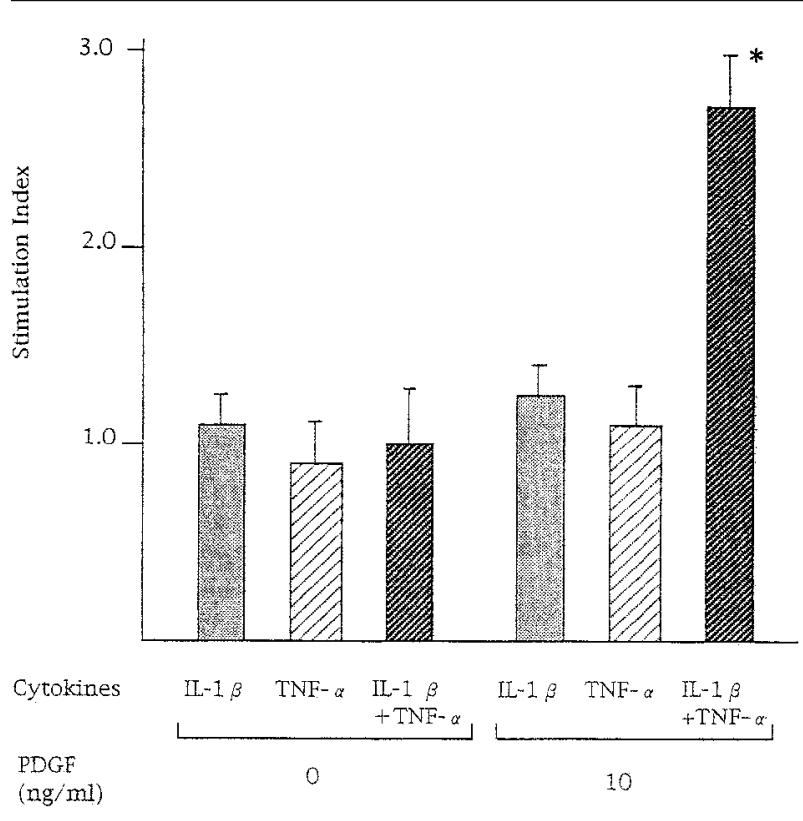

FIG. 5. Fibroblast chemotaxis treated with PDGF, IL-1 $\beta$, or TNF- $\alpha$ for $8 \mathrm{~h}$. Responses are expressed as SI. The SI was calculated as described in Materials and Methods. Each bar is the average of triplicate values. Four experiments were performed. $p<0.05$ compared with PDGF.

cell proliferation and remodeling. These phenomena are induced by growth factors and cytokines produced by infiltrating platelets, macrophages, fibroblasts and residential cells. Of particular interest is the role of PDGF in this process given the recently reported finding that PDGF-like proteins are localized in macrophages and epithelial cells of patients with idiopathic pulmonary fibrosis. ${ }^{17-21}$ Lung fibroblasts are also reported to be capable of synthesizing growth factors known to stimulate fibroblast proliferation in vivo, which in turn suggests an autocrine pathway for proliferation of these cells. ${ }^{21-24}$

Cytokines such as TNF- $\alpha$ have also been reported to stimulate PDGF secretion-dependent fibroblast proliferation. ${ }^{25,26}$ Several experiments have demonstrated that lung fibroblasts have different potentials to produce collagenase during the development of pulmonary fibrosis. ${ }^{27-29}$ However, little is known concerning the interaction between PDGF, IL-1 $\beta$ and TNF- $\alpha$ during pulmonary inflammation. We have demonstrated that PDGF in combination with IL-1 $\beta$ and TNF- $\alpha$ stimulated the lung fibroblast production of MMP-3 and MMP-9. Under similar conditions, the proliferation, but not the migration, of lung fibroblasts was inhibited.

Bronchoalveolar lavage fluid from patients with idiopathic fibrosis contain a high level of active collagenase. $^{30}$ Matrix metalloproteinases, such as MMP-1, MMP-3 and MMP-9, are important in catalyzing the destruction of collagen, fibronectin, gelatin and other extracellular matrix proteins in inflammation. Tumor cells in culture with metastatic potential have been demonstrated to secrete MMPs. ${ }^{14,15}$ Cytokines including TGF- $\alpha$ and IL-1 $\beta$ augmented the synthesis of MMP-9 in murine skin fibroblasts. ${ }^{31}$ Our experiments suggested that MMP-1 and MMP-2 were spontaneously released, whereas MMP-3 and MMP-9 were not from human lung fibroblasts. In addition, MMP- 3 and MMP-9 were also not induced by PDGF alone. In contrast, IL-1 $\beta$ stimulates MMP -3 production while TNF- $\alpha$ stimulates MMP-9 production. Furthermore, we provided evidence for the coordination of the effects of IL- $1 \beta$ and TNF- $\alpha$ in reducing MMP-3 and MMP-9 production. However, the major finding of the present study was the synergistic production of MMP-3 and MMP-9 induced by PDGF combined with IL- $1 \beta$, TNF- $\alpha$ and both cytokines. This finding suggested that PDGF has a complex impact on MMP production in human lung fibroblasts, with the mechanism underlying this effect remaining to be established. A possible mechanism may involve PDGF acting on the transcription pathway.

IL- $1 \beta$ and TNF- $\alpha$ have been reported to enhance and inhibit respective collagen production in lung fibroblasts. ${ }^{28}$ We have shown that IL- $1 \beta$ and TNF- $\alpha$ had no effect of fibronectin production. PDGF had an effect on fibronectin production, which was not augmented by IL- $1 \beta$ and TNF- $\alpha$. Under these conditions, PDGF may play the main role in human lung proliferation and contribute to cell migration in the early stages of inflammation. PDGF is released from $\alpha$-granules found in platelets and is not only a mitogen for connective tissue cells in vitro, but is also a potent chemotactic agent for fibroblasts and smooth muscle cells. $^{32-34}$ IL- $1 \beta$ alone and TNF- $\alpha$ alone had no synergistic effect on PDGF-induced fibroblast proliferation in this experiment (data not shown). In the presence of IL-1 $\beta$ and TNF- $\alpha$, the proliferation induced by PDGF was inhibited, while the chemotactic response to PDGF was increased.

It is known that IL-1 $\beta$ stimulates the release of $\mathrm{PGE}_{2}$, which in turn inhibits fibroblast proliferation..$^{35,36}$ Our experiment suggested that under our experimental conditions, $\mathrm{PGE}_{2}$ does not play a role in fibroblast proliferation. Indomethacine did not reverse the inhibitory effects of IL- $1 \beta$ and TNF- $\alpha$ on fibroblast proliferation (data not shown). These results suggest that the inhibition caused by the combination of these cytokines is unrelated to fibloblast prostaglandine synthesis. Transmodulation of the PDGF receptor by IL-1 $\beta$ or the transmodulation of the FGF receptor by PDGF have been shown to occur in other systems. ${ }^{37,38}$ The possibility exists that PDGF modulates IL- $1 \beta$ and TNF- $\alpha$ receptor expression.

The present results indicated that PDGF in combination with IL- $1 \beta$ and TNF- $\alpha$ differentially regulated metalloproteinase production, proliferation activity and the chemotactic response in lung fibroblasts. 
ACKNOWLEDGEMENTS. We wish to thank Dr J. Miyazaki (Yokohama City University) for his help in zymographic analysis of metalloproteinases. This work was supported in part by a Grant-in-Aid for Scientific Research C (07670653) from the Ministry of Education, Science and Culture, Japan.

\section{References}

1. Fukuda Y, Isizaki M, MasudaY, Kimura G, Kawanami O, Masugi Y. The role of intraalveolar fibrosis in the process of pulmonary structural remodeling in patients with diffuse alveolar damage. Am J Pathol 1987; 126:171-182

2. Pard A, Selman M, Ramirez R, Ramos C, Montano M, Stricklin G, Raghu G. Production of collagenase and tissue inhibitor of metalloproteinases by fibroblasts derived from normal and fibrotic human lungs. Chest 1992 102:1085-9

3. Unemori E N, Ehsani N, Wang M, Lee S, McGuire J, Amento E P Interleukin- 1 and transforming growth factor- $\alpha$ : synergistic stimulation of metalloproteinases, PGE2 and proliferation in human fibroblasts. Exp Cell Res 1994; 210:166-71

4. Soma Y, Takehara K, Isibashi Y. Alteration of chemotactic response of human skin fibroblasts to PDGF by growth factors. Exp Cell Res 1994 212:274-7

5. Seppa H, Grotendorst G, Seppa S, Schiffmann E, Martin GR. Plateletderived growth factor is chemotactic for fibroblasts. I Cell Biol 1982 92:584-8

6. Battegay EJ, Rains EW, Colbert T, Ross R. TNF- $\alpha$ stimulation of fibroblast proliferation. I Im mu nol 1995; 154:6040-7

7. Schmidt JA, Mizel SB, Cohen D, Green I. Interleukin-1, a potent regulator of fibroblast proliferation. J Im munol 1982; 128:2177-82

8. Duncan MR, Berman B. Differential regulation of collagen, glycosaminoglycan, fibronectin, collagenase activity production in cultured human adult dermal fibroblasts interleukin1-alpha and beta and tumor necrosis factor-alpha and beta. J Invest Derm a tol 1989; 92:699-706

9. Erkell LJ, Schirrmach V. Quantitative in vitro assay for tumor cell invasion through extracellular matrix or into protein gels. Cancer Res 1988; 48:6933-7

10. Umenishi F, Umeda M, Miyazaki K. Efficient purification of TIMP-2 from culture medium conditioned by human hepatoma cell line, and its inhibitory effects on metalloproteinases and in vitro tumor invasion. $J$ Biochem 1991; 110;189-95

11. Miyazaki K, Hattori Y, Umenishi F, Yasumitu H, Umeda M. Purification and characterization of extracellular matrix-degrading metalloproteinase, matrin(pump-1), secreted from human rectal carcinoma cell line. Cancer Res 1990; 50:7758-64

12. Ura H, Bonifil D, Reich R, Reddel R, Pfeifer A, Harris CC. Expression of type IV collagenase and procollageneses and its correlation with tumorigenic invasive, and metastatic abilities of oncogene-transformed human bronchial epithelial cells. Cancer Res 1989; 49:4615-21

13. Matrisiam LA, Bowden Y. Stromelysin/transin and tumor progression Sem in Cancer Biol 1990; 1:107-15

14. Chin JR, Murphy G, Werb Z. Stromelysin, a connective tissue-degrading metaloendopeptidase secreted by stimulated rabbit synovial fibroblasts in parallel with collagenase. J Biol Chem 1985; 260:12367-76

15. Bienkowski RS, Gotkin MG. Control of collagen deposition in mammalian lung. Proc Soc Exp Biol Med 1995; 209:118-40

16. Harris ED, Vater CA. Methods in Enzymology. 1982; 82:423-452

17. Selman M, Montano M, Ramos C, Chapel R. Coccentration, biosynthesis and degradation of collagen in idiopathic pulmonary fibrosis. Tho rax 1986; 41:355-9

18. Rennard SI, Hunninghake GW, Bitterman PB, Crystal RG. Production of fibronectin by human alveolar macrophage: mechanism for the recruitment of fibroblast to sites of tissue injury in interstitial lung diseases. Proc Natl Acad Sci USA 1981; 78:7147-51

19. Martinet Y, Rom WN, Grotendorst GR, Martin GR, Crystal RG. Exaggerated spontaneous release of platelet-derived growth factor by alveolar macrophages from patients with idiopathic pulmonary fibrosis. $N$ EnglJ Med 1987; 317:202-9
20. Antoniades HA, Bravo MA, Avila RE, Galanopoulos T, Neville-Golden J, Maxwell M, Selman M. Platelet-derived growth factor in pulmonary fibrosis. J Clin Invest 1990; 86:1055-64

21. Vignaud JM, Allam M, Martient N, Pech M, Plenant F, Martient Y. Presence of platelet-derived growth factor in normal and fibrotic lung is specifically associated with interstitial macrophages, while both interstitial macrophages and alveolar epithelial cells express the c-sis protooncogene. Am J Resp Cell Mol Biol 1991; 5:531-8

22. Butler DM, Leizer T, Hamilton JA. Stimulation of human synovial fibroblast DNA synthesis by platelet-derived growth factor and fibroblast growth factor. JIm mu nol 1989; 142:3098-103

23. Tingstorm A, Reuterdahl C, Lindahl P, Heldin C, Rubin K. Expression of platelet-derived growth factor- $\beta$ receptors on human fibroblasts. $J$ Im munol 1992; 148:546-54

24. Rojas-Valencia L, Montiel F, Montano M, Selman M, Pardo A. Expression of a 2.8 -kb PDGF-/c-sis transcript and synthesis of PDGF-like protein by human lung fibroblasts. Chest $1995 ; 108: 240-5$

25. Paulsson Y, Austgulen R, Hofsli E, Heldin C, Westermark B, Nissen-Meyer J. Tumor necrosis factor-induced expression of platelet-derived growth factor A chain messenger RNA in fibroblasts. Exp Cell Res 1989; 180:490-6

26. Battegay EJ, Raines EW, Colbert T, Ross R. TNF- $\alpha$ stimulation of fibroblast proliferation dependence on platelet -derived growth factor (PDGF) secretion and alternation of PDGF receptor expression. J Immunol $1995 ; 154: 6040-7$

27. Zeng G, Millis AJT. Differential regulation of collagenase and stromelysin mRNA in late passage cultures of human fibroblasts. Exp Cell Res 1996; 222:150-6

28. Elias J, Freeundlich B, Adams S, Rosenbloom J. Regulation of human lung fibroblast collagen production by recombinant interleukin-1, tumor necrosis factor, and interferon- $\gamma$. Ann NY Acad Sci 1990; 580:233-44

29. Circolo A, Welgus HG, Pierce GF, Kramer J, Strunk RC. Differential regulation of the expression of proteinases/antiproteinases in fibroblasts. J Biol Chem 1991; 266:12283-8

30. Gadek JE, Kelman JA, Fillus G, Weinberger SE, Horwitz AL, Reynolds HY, Fulmer JD, Crystal RG. Collagenase in the lower respiratory tract of patients with idiopathic pulmonary fibrosis. $N$ Engl J Med 1979; 301:737-42

31. Miyagi E, Yasunitu H, Hirahara F, Nagashima Y, Minaguchi H, Miyazaki K, Umeda M. Marked induction of gelatinases, especially type B, in host fibroblasts by human ovarian cancer cells in athymic mice. Clin Exp Metastasis1995; 13:89-96

32. Ross R, Raines EW, Bowen-Pope DF. The biology of platelet-derived growth factor. Cell 1986; 46:155-69

33. Senior RM, Griffin GL, Huang LJS, Walz DA, Deuel TF. Chemotactic activity of platelet alpha granile proteins for fibroblasts. J Cell Biol 1982; 92:382-5

34. Grotendorst GR, Seppa EJ, Kleinman HK, Martin GR. Attachment of smooth muscle cells to collagen and their migration toward plateletderived growth factor. Proc Natl Acad Sci USA 1981; 78:3669-72

35. Lin LL, Lin AY, Dewitt DL. Interleukin-1induces the accumulation of cytosolic phospholipase A2 and the release of prostaglandin E2 in human fibroblasts. J Biol Chem 1992; 267:23451-4

36. Elias JA, Gustilo K, Baeder W, Freundlich B. Synergistic stimulation of fibroblast prostaglandine production by recombinant interleukin 1 and tumor necrosis factor. I Im mo nol 1987; 138:3812-16

37. Tsukamoto T, Matui T, Nakata H, Ito M, Natazuka T, Fukase M, Fujita T Interleukin-1 enhances the response of osteoblasts to platelet-derived growth factor through the receptor-specific up-regulation. $J$ Biol Chem $1991 ; 266: 10143-7$

38. Landgren E, Eriksson A, Wennstrom S, Kanda S, Claesson-Welsh L. Induction of fibroblast growth factor receptor-1 mRNA and protein by platelet-derived growth factor bb. Exp Cell Res 1996; 223:405-11

\section{Received 25 June 2000; accepted 28 July 2000}




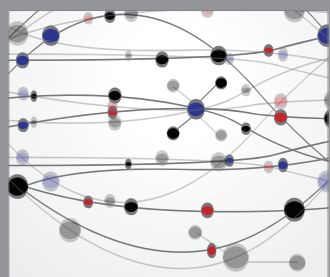

The Scientific World Journal
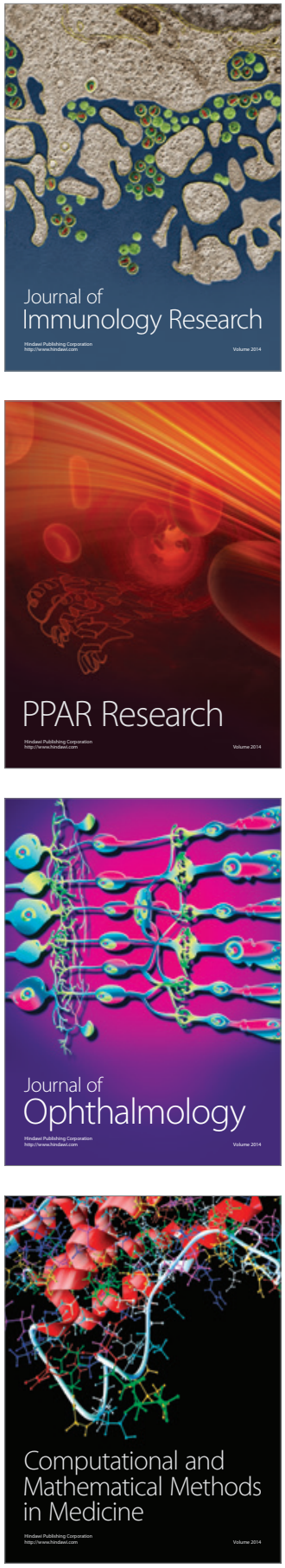

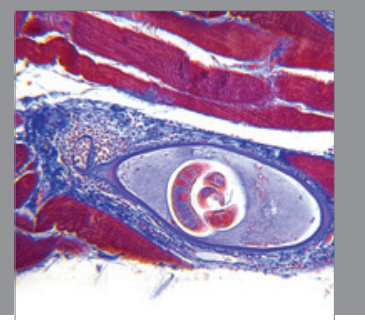

Gastroenterology

Research and Practice
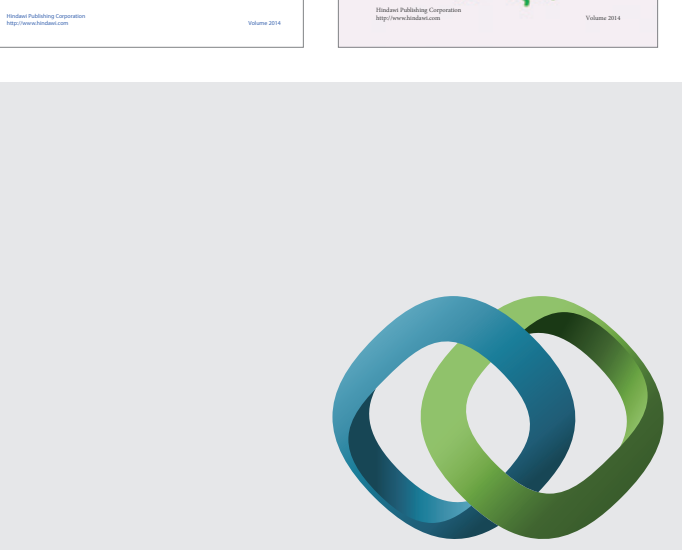

\section{Hindawi}

Submit your manuscripts at

http://www.hindawi.com
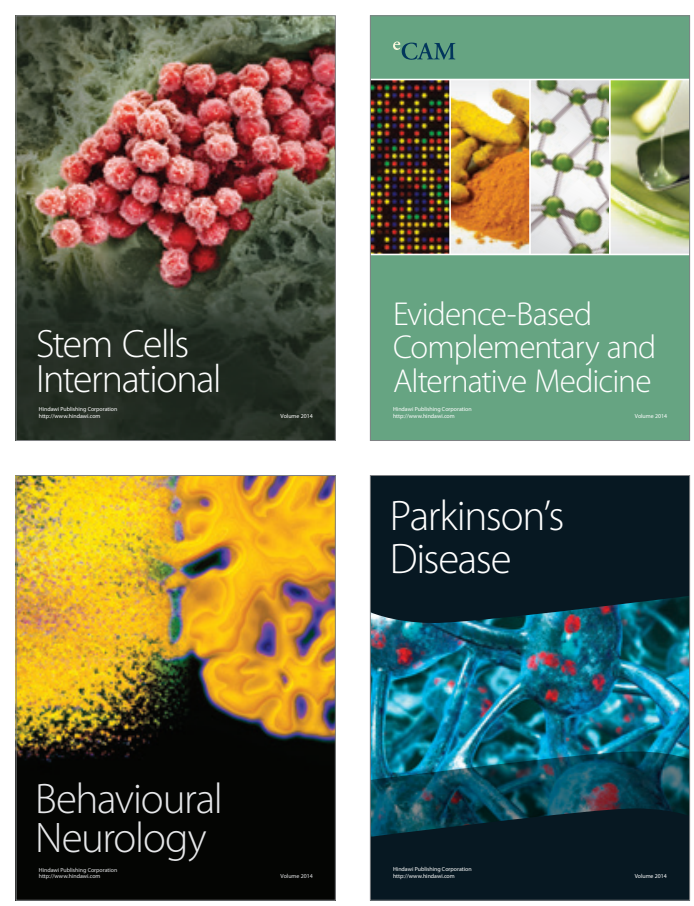

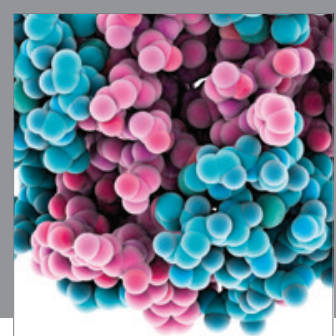

Journal of
Diabetes Research

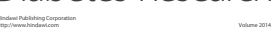

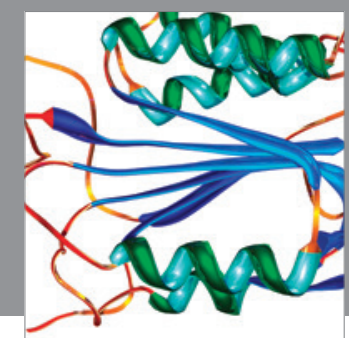

Disease Markers
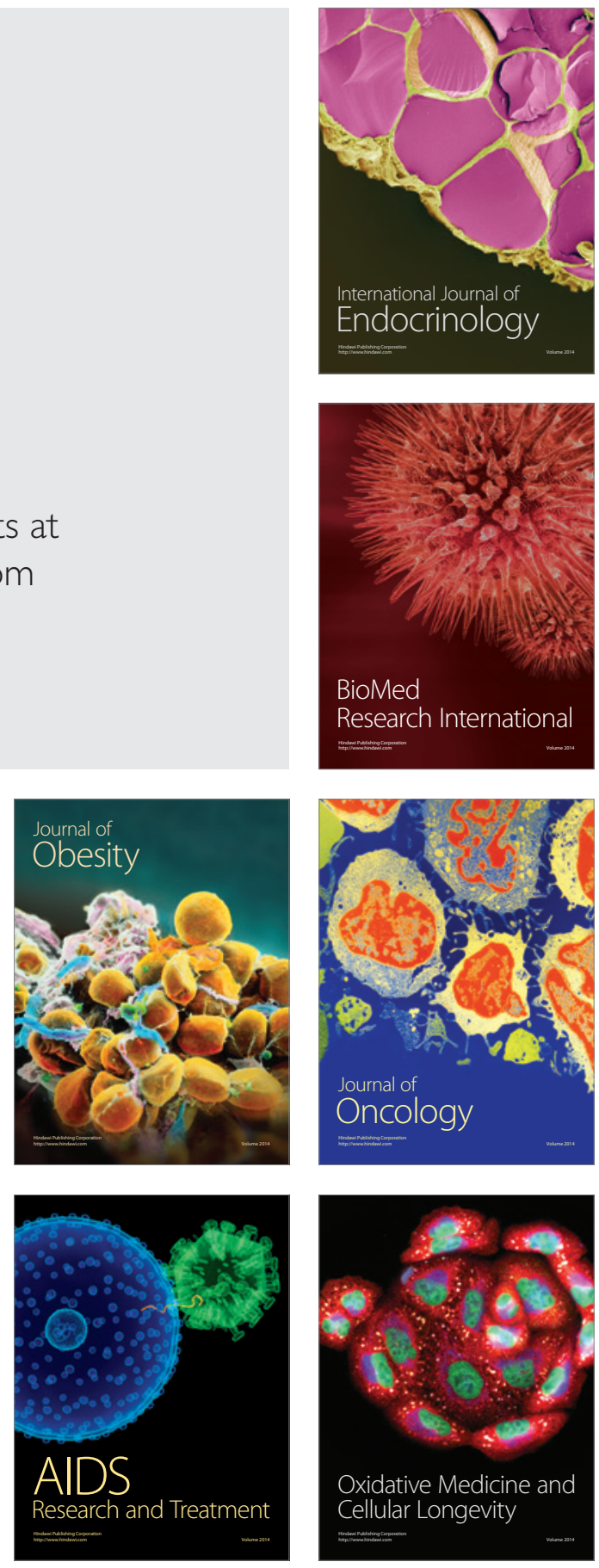